\title{
Bioaccumulation, Hepatotoxicity, Immune Response and Growth in Oreochromis niloticus Exposed to Cadmium
}

\author{
Driele Ventura de Paulo ${ }^{1}$, Laís Leal Lopes ${ }^{2}$, Arielle Oliveira Cruz das Neves ${ }^{2}$, Francisco Oliveira de \\ Magalhães Júnior ${ }^{3}$,Raildo Mota de Jesus ${ }^{4}$, Luiz Gustavo Tavares Braga ${ }^{3}$, Fábio Flores Lopes ${ }^{*}$

\begin{abstract}
1Ecotoxicology Research, Laboratory of Zoology Department, Federal University of Pernambuco, Recife, Brazil
${ }^{2}$ Histology Research, Laboratory of Biological Sciences Department in the Southern Bahia, State University of Santa Cruz, Ilhéus, Brazil

${ }^{3}$ Nutrition and Fish Feeding Research (AQUANUT), Laboratory of Agronomic Engineering Department in the Southern Bahia, State University of Santa Cruz, Ilhéus, Brazil

${ }^{4}$ Analytical Chemistry Research, Laboratory of Chemistry Department in the Southern Bahia, State University of Santa Cruz, Ilhéus, Brazil
\end{abstract}

*Corresponding Author

Received: $13^{\text {th }}$ December, 2019

Accepted: $16^{\text {th }}$ January, 2020

Published online: $13^{\text {th }}$ February, 2020

https://doi.org/10.33745/ijzi.2020.v06i01.001

\begin{abstract}
The use of cadmium as additives in agricultural products has been one of the current anthropogenic sources harmful to the health of aquatic animals. 200 juveniles of Oreochromis niloticus $(0.88 \mathrm{~g} \pm 0.2)$ were exposed for 21 days to clean water (control) and increasing concentrations of cadmium $\left(0.4,2,4.1\right.$ and $7.5 \mathrm{mg} \mathrm{L}^{-1}$ ). Every 7 days of exposure, eight fish from each treatment were anesthetized and euthanized and total weight, liver weight and length of fish were measured. Four specimens of each treatment were taken for bioaccumulation analysis and four for histopathological analysis. The $96 \mathrm{~h} \mathrm{LC}_{50}$ was estimated to be $1.8 \mathrm{mg} \mathrm{L}^{-1}$. High bioaccumulation in fish liver and bioaccumulation factor $(\mathrm{BCF}=327)$ of this trace metal were noticed at lowest concentration of $0.4 \mathrm{mg} \mathrm{L}^{-1}$ at 21 days of exposure. The results of HAI index reflected a hepatotoxic tendency dependent on concentration of cadmium which triggered moderate and severe histopathologies. Hepatomegaly was noticed in fish exposed to all concentrations in relation to control. There was a significant reduction in weight of individual exposed to $2 \mathrm{mg} \mathrm{L}^{-1}$, evidencing that in case of contamination productive performance was affected, reducing weight and length of individuals. Thus, in aquatic contamination, a cadmium bioaccumulation in the liver may evolve histopathological responses and eventually induce hepatomegaly, weight gain reduction and growth reduction of fish. Thus, an evaluation of these portrayed changes may reveal the structural, physiological and survival conditions of fish under recruitment under conditions of environmental contamination.
\end{abstract}

Keywords: Nile tilapia, Bioaccumulation, Hepatotoxicity, Blood toxicity, Weight acquisition, Cadmium, Liver

Citation: Driele Ventura de Paulo, Laís Leal Lopes, Arielle Oliveira Cruz das Neves, Francisco Oliveira de Magalhães Júnior, Raildo Mota de Jesus, Luiz Gustavo Tavares Bragaand Fábio Flores Lopes: Bioaccumulation, hepatotoxicity, immune response and growth in Oreochromis niloticus exposed to cadmium. Intern. J. Zool. Invest. 6 (1): 01-20, 2020. https://doi.org/10.33745/ijzi.2020.v06i01.001 


\section{Introduction}

Contamination and mobility of contaminants in an ecosystem can occur through natural and anthropogenic activities. The flow and deposition of soil metals in bodies of water can influence the surface water quality and cause potential impacts on ecosystems (Abraham et al., 2017). Cadmium (Cd) is an example of trace toxic metal which occurs mainly as a component of minerals in earth's crust at an average concentration of $0.18 \mathrm{ppm}$ (Babich and Stotzky, 1978). It is widely used in various anthropic uses, such as in mining activities or in the manufacture of batteries, pigments (Zang and Bolger, 2014) and fungicides and organophosphate fertilizers (Fristachi and Choudhury, 2017) used for correction or soils nutrition in agriculture (Singh et al., 2010). Among the forms of environmental contamination by this metal, anthropogenic sources correspond to more than $90 \%$ of the contamination in surface waters, and the application of phosphate fertilizers in agriculture is responsible for releasing 33 to $56 \%$ of the anthropogenic substance into the environment in the Europe (USEPA, 2016).

Once present in soils, this contaminant can be mobilized to the aquatic environment by leaching processes, causing considerable increase of its concentration in freshwater environments. In Sri Lanka, the use of agricultural chemicals in rice growing areas has been considered as a major source of contamination of this metal in the aquatic environment (Ileperuma, 2000; Jayasumana et al., 2014; Perera et al., 2016).

Concentrations of cadmium were recorded in samples from cocoa powder and chocolate
(0.207 and $0.303 \mathrm{mg} \mathrm{kg}^{-1}$, respectively) in Italy and the main source of transmission was related to the artificial contamination of the soil cocoa plants (Lo Dico et al., 2018). Researches carried out in the Cachoeira river which bathes stretches of agricultural areas of cocoa cultivation in southeastern Bahia, Brazil, showed that the contamination and eutrophication of the river was associated with the flow of metals from the cultivated lands (Klumpp et al., 2002). Moreover, in Sepetiba Bay, to the state of Rio de Janeiro, Brazil, it was observed that $\mathrm{Cd}$ level was above the legislation levels, with average $\mathrm{Cd}$ concentration at $1.55 \mathrm{mg} \mathrm{L}^{-1}$ in water, $7.02 \mathrm{mg}$ $\mathrm{kg}^{-1}$ in sediment, $6.08 \mathrm{mg} \mathrm{kg}^{-1}$ and $7.6 \mathrm{mg} \mathrm{kg}^{-1}$ for kidney and liver of aquatic birds.

In this way, there are concerns about the environmental risks caused by exposure to this serious environmental pollutant which can induce a wide spectrum of toxic effects in fish plants and humans (Zang and Bolger, 2014; Pereira et al., 2017; Sanches Filho et al., 2017). In fish the specialized literature reports diverse physiological effects caused by exposure to cadmium, such as bioaccumulation in tissues causing oxidative stress and hepatic alterations in Danio rerio (Duan et al., 2017), imbalance of plasma ion concentrations in Platichthys flexus (Larsson et al., 1981) and Heteropneustes fossilis (Rai et al., 2009), inhibition of circulating estradiol and hepatic vitellogenin in Pimephales promelas (Driessnack et al., 2017), reduction of the hatching rate of Pagrus major by up to 100\% (Cao et al., 2009), inhibition of skeletal calcification processes in Salmo solar fingerlings (Rombough and Garside,1984) and 
induction of carcinogenic effects (Babich et al., 1986). In addition, cadmium has been reported to accumulate in fish liver and kidney and its low ability to accumulate in muscle tissues (Cinier et al., 1997).

Brazilian federal laws regulate acceptable concentrations of $\mathrm{Cd}$ in freshwater environments as well as metal levels in different types of food according to Federal Resolution 518/2004 for fish and fishery (the acceptable limit is $1 \mu \mathrm{g} / \mathrm{kg} /$ day).

Thus, the use of histopathological analyzes of specific target structural organs has been recognized as an effective tool in studies and diagnoses of acute and chronic diseases (Oliveira Ribeiro et al., 2002; Ribeiro et al., 2005). Exposure to cadmium may promote histopathological changes in various tissues and organs. In the liver it promotes changes such as hepatocytes vacuolization (Samanta et al., 2018) and vessel congestion (van Dyk et al., 2007). Thus, a histopathological investigation of this organ associated with a holistic investigation of the exposed organisms can produce significant results.

Oreochromis niloticus (Linnaeus, 1758) is an exotic species, resistant to variations of dissolved oxygen concentration in the water and parameters related to the deterioration process of this environment. However, this species has been used in ecotoxicological trials because it is sensitive to evaluate the effects of chemical contaminants present in the aquatic environment, besides being able to develop behavioral, physiological and biochemical adjustments that allow them to live in unfavorable environmental conditions.

The present study aimed to evaluate the toxic potential of cadmium in Oreochromis niloticus juveniles with different levels of biomarkers, in order to verify the lethal effect of this contaminant, bioaccumulation in the liver, the degree of histopathological changes in organ, the physiological responses from the hepatosomatic index and the fishes productive performance, which was evaluated by the specimens growth, thus collaborating for a holistic and integrative understanding of this contaminant toxic effect on a sensitive species of a great economic importance.

\section{Materials and Methods}

A bioassay test was carried out at Laboratory of Nutrition and Fish Feeding (AQUANUT), at the State University of Santa Cruz, Ilhéus, BA, Brazil, in the period of 21 days.

\section{Fish cultivation and feeding:}

Masculine specimens of 0 . niloticus were obtained from the Aquavale fish farm, located in Ituberá, Bahia, Brazil (-13.744108 $39.1577^{\prime} 74$ "), with a mean weight of $0.88 \pm$ $0.2 \mathrm{~g}$ and a total length of $37.5 \pm 3.3 \mathrm{~mm}$.

The specimens were transferred to two tanks (each having capacity of $310 \mathrm{~L}$ ) in the AQUANUT, where they passed through a 5 days adaptation period. After this period, 200 juveniles of $O$. niloticus were used in 20 glass aquaria each having capacity of $30 \mathrm{~L}$ (10 fish/aquarium). The physical and chemical water variables were measured with multiparameter instruments (Probe YSI Professional Plus, HI9146-04 portable oximeter with $0.1 \mathrm{mg} \mathrm{L}^{-1}$ precision and HI991300 portable multiparameter). Feeding was done three times a day with extruded meal commercial feed, with $40 \%$ crude protein, adjusted until the satiety of the individuals, in order to obtain the minimum of leftovers. The feeding was suspended $24 \mathrm{~h}$ before the start of the experiment and every $12 \mathrm{~h}$ before the weekly fish collection, in order 
to avoid the accumulation of organic matter in the aquaria.

\section{Preparation of the cadmium chloride solution:}

The cadmium chloride solution $\mathrm{CdCl}_{2} .5 \mathrm{H}_{2} \mathrm{O}$ (Merck Darmstadt, Germany) was prepared from the dissolution of $6.0955 \mathrm{mg}$ of this compound in ethanol, obtaining $3000 \mathrm{mg} \mathrm{L}^{-1}$ of cadmium concentration.

\section{Experimental design:}

The bioassay design was completely randomized, with four replicates for each treatment and in the control group. Different volumes of these solutions were pipetted once in aquarium with a volume of $30 \mathrm{~L}$ of fresh water in order to generate concentrations of Cd $\left(0.4,2.0,4.1\right.$ and $\left.7.5 \mathrm{mg} \mathrm{L}^{-1}\right)$.

During the experiment, two fish from each aquarium (eight fish per treatment) were used to analyze leukogram and to establish the hepatosomatic index. For weekly monitoring of liver bioaccumulation and histopathological changes in the liver, four liver samples were used for each type of weekly analysis by treatment. All individuals were euthanized with super dosage of commercial benzocaine ( $3 \mathrm{~g} \mathrm{~L}^{-1}$ ), followed by the procedures recommended by the Canadian Council on Animal Care (2005, 1998), American Fisheries Society and American Veterinary Medical Association (1998), for studies with fish kept in ice water, temperature between 0 and $-4 \mathrm{C}$, for 10 minutes until paralysis of the opercular movement. Cervical incision was performed before liver removal for histological analysis and bioaccumulation. In each treatment, samplings were performed every seven days during a period of 21 days, using 40 samples of 0 . niloticus weekly, totaling 160 individuals at the end of the experiment. The blood samples used 8 fish per treatment weekly. The sublethal effect assessments including bioaccumulation of this contaminant in the liver were performed only on fish exposed to concentrations of 0.4 and $2 \mathrm{mg} \mathrm{L}^{-1}$.

\section{Mortality:}

To evaluate the fish mortality exposed to the chemical, the number of dead fish per day was recorded in each treatment. The 50\% lethal concentration of exposed individuals after 96 $\mathrm{h}$ of exposure (96h-LC50) was calculated using the method "Trimmed-Spearman-Karber (TSK)" (USEPA, 2002).

\section{Cadmium concentration in water and liver:}

Water samples were taken from the aquaria at the beginning and at the end of 21 days of exposure. These samples were acidified with nitric acid (Merck, Darmstadt, Germany) to determine the actual $\mathrm{Cd}$ concentrations in the aquaria. To evaluate the trace metal bioaccumulation in fish, eight liver samples were taken weekly from the specimens of each treatment. Samples were weighed, digested in a digester block with digestion tubes with coupled finger to avoid losses of $\mathrm{Cd}$ by volatilization. An external calibration with a multielementary standard at the concentration of $1000 \mathrm{mg} \mathrm{L}^{-1}$ was performed, with successive dilution to the calibration curve in the range of 0.1 to $2 \mathrm{mg} \mathrm{L}^{-1}$ for quantification of $\mathrm{Cd}$ concentration.

The water and liver samples were analyzed using Inductively Coupled Plasma Optical Emission Spectrometry (ICP OES) model 710 ES Varian (Mulgrave, Australia), equipped with Agilent (Santa Clara, USA), chamber of cyclonic nebulization single pass Varian (Mulgrave, Australia), with axial configuration and solid-state detector with CCD array (charge coupled device). The 
analytical emission line selected for $\mathrm{Cd}$ determination was 214,439 . To evaluate the accumulation of cadmium in the liver of the exposed individuals in relation to the metal concentration in the water, the Bioconcentration Factor (BCF) (Barron, 1995) was used $(\mathrm{BCF}=$ concentration of a chemical in an organism/concentration of the chemical in the environment) for the juveniles exposed to 0.4 and $2 \mathrm{mg} \mathrm{L}^{-1}$. Liver content on $14^{\text {th }}$ day was quantified only in fish survival.

\section{Hematologic Analysis and Leukogram:}

Blood samples were obtained through cardiac puncture using disposable syringes containing EDTA (10\%). Blood was collected from each fish for total cell count in the Neubauer chamber and smear preparation for subsequent differential counts in duplicates. Hematopoietic tissue analysis was performed according to Ishikawa et al. (2008), through the differentiation of the defense blood cells (leukocytes and thrombocytes) and morphological evaluation of the cells in the smears pancromatically stained by the methods of Whrite and Panótico. The leukocyte count, or leukogram, followed the work of Tavares-Dias and Moraes (2003), where 100 leukocytes were counted in each extension, establishing the percentage of each cellular component. For this count of leukocytes, optic microscopy was used for direct observation after staining and a cell counter adapted for blood cells. Five fields were analyzed in the $100 \mathrm{X}$ objective and the leukocyte count ended when the 1000 red blood cell count was reached as a reference.

\section{Hepatosomatic Index:}

In order to verify the percentage of liver mass in relation to body weight, the hepatosomatic index (HSI) of each individual was determined by treatment and it was calculated by the ratio of liver weight to total body weight of 100 . The HSI values obtained were compared with the liver histopathological findings.

Histopathological Analysis:

The fish was euthanized with benzocaine and ice water and fixed in 10\% formaldehyde. The livers were removed and preserved in 70\% alcohol. For the tissues analysis, the routine histological technique of dehydration in ethyl alcohol was used for impregnation and inclusion in paraffin (Paulo et al., 2012). The sections were cut at 5 to $7 \mu \mathrm{m}$ and stained with Hematoxylin and Eosin (HE). Ten sections of each fish were analyzed and structural changes were photographed (Leica DM3000).

Histopathological changes in the liver were semi-quantitatively evaluated by the degree of tissue change (Histopathological Alteration Index - HAI) based on lesions severity. For calculating HAI, changes in each organ were classified into progressive stages of tissue damage (modified from Poleksic and Mitrovic-Tutundzic, 1994). An HAI value was calculated for each animal by the formula: HAI $=(1 \mathrm{X} \mathrm{SI})+(10 \mathrm{X} \mathrm{SII})+(100 \mathrm{X}$ SIII $)$; where I, II and III correspond to the number of stages of alterations 1, 2 and 3 , and $S$ represents the sum of a certain stage alterations. The mild, moderate and severe alterations were classified with degree of severity 1, 2 and 3 respectively. HAI values between 0 and 10 indicated normal organ function; values between 11 and 20 indicated slight damage to the organ; between 21 and 50 indicated moderate changes in the organ; values between 50 and 100 indicated severe lesions and values above 100 indicated irreparable 
organ damage (Poleksic and MitrovicTutundzic, 1994).

Productive performance and growth:

To evaluate the productive performance of masculinised $O$. niloticus under treatment with cadmium, the growth of the individuals during the 21 days of exposure was evaluated. At the beginning of the experiment and after the 21-day exposure the standard length (CP) and total weight gain (GP) in the specimens were taken for growth assessments, checking the length $(\mathrm{mm}) \quad \mathrm{CP}=\mathrm{Cf}$ (final length) $-\mathrm{Ci}$ (initial length); and weight gain (g) GP = Pf (final weight) -Pi (initial weight) of the juveniles for each treatment.

\section{Statistical Analysis:}

To assess the individuals mortality after 96 hours of exposure to cadmium, the concentration capable of generating lethality in $50 \%$ of individuals (96h-LC50) was estimated using the non-parametric "Trimmed-Spearman-Karber (TSK)" test. For the parameters of bioaccumulation, hematology analyzes, histopathological analyzes and growth, the different treatments were compared with the control using analysis of variance (ANOVA) and Dunnett test to verify differences between control and treatments. When no normality (KolmogorovSmirnov test) or homoscedasticity (Levene median test) was observed, Kruskall-Wallis non-parametric test (KW) was applied, followed by the Dunn test to evaluate differences between control and treatments. SigmaPlot software version 12 (Jandel Scientific, Erkrath, Germany) was used with a $5 \%$ alpha.

\section{Results}

The physical and chemical conditions of water remained constant throughout the period of exposure of $O$. niloticus to the metal. The nitrate concentrations did not exceed $12.5 \mathrm{mg}$ $\mathrm{L}^{-1}$. Among the water quality parameters analyzed, there was no statistically significant difference between (ANOVA) treatments 0.4, 2, 4.1 and $7.5 \mathrm{mg} \mathrm{L}^{-1}$ in relation to the control. The values were within the tolerance allowed for the species (Svobodova et al., 2017).

\section{Mortality:}

O. niloticus specimens exposed to increasing cadmium concentrations presented 96h- $\mathrm{LC}_{50}$ as $1.8 \mathrm{mg} \mathrm{L}^{-1}$ (LC95\% inf-sup $=1.6-2.5 \mathrm{mg} \mathrm{L}^{-1}$ ). After $24 \mathrm{~h}, 75 \%$ of mortality was observed in the individuals exposed to the concentrations $7.5 \mathrm{mg} \mathrm{L}^{-1}, 39 \%$ in $4.5 \mathrm{mg} \mathrm{L}^{-1}$ and $6 \%$ in $2.5 \mathrm{mg}$ $\mathrm{L}^{-1}$, with loss of the swimming balance of the survivors. The concentration of $0.4 \mathrm{mg} \mathrm{L}^{-1}$ not promote mortality. Sublethal effects and bioaccumulation were analyzed only in the samples exposed to 0.4 and $2.0 \mathrm{mg} \mathrm{L}^{-1}$.

Cadmium concentration in water and in the liver:

The determination of the nominal cadmium concentration in the water showed that the mean values of the initial real concentrations were $0,0.4,2.0,4.1,7.5 \mathrm{mg} \mathrm{L}^{-1}$ and at the end of 21 days were $0,0.3,1.5,3.6,7.0 \mathrm{mg} \mathrm{L}^{-1}$.

The mean values of this trace metal found in the liver of individuals exposed to 0.4 and 2 $\mathrm{mg} \mathrm{L}^{-1}$ after day 7 was 16.7 and 98.2 and after day 21 was 105.0 and $136.0 \mathrm{mg} \mathrm{G}^{-1}$, respectively. A significant increase in the bioaccumulation in the liver of juveniles exposed to $2 \mathrm{mg} \mathrm{L}^{-1}$ was detected in relation to the control in 14 days of exposure probably due to a reduction in detoxification capacity (ANOVA- F5,2 $=11.6, \mathrm{p}=0.013$, Dunnett $\mathrm{p}$ $<0.05$ ) (Fig. 1). 

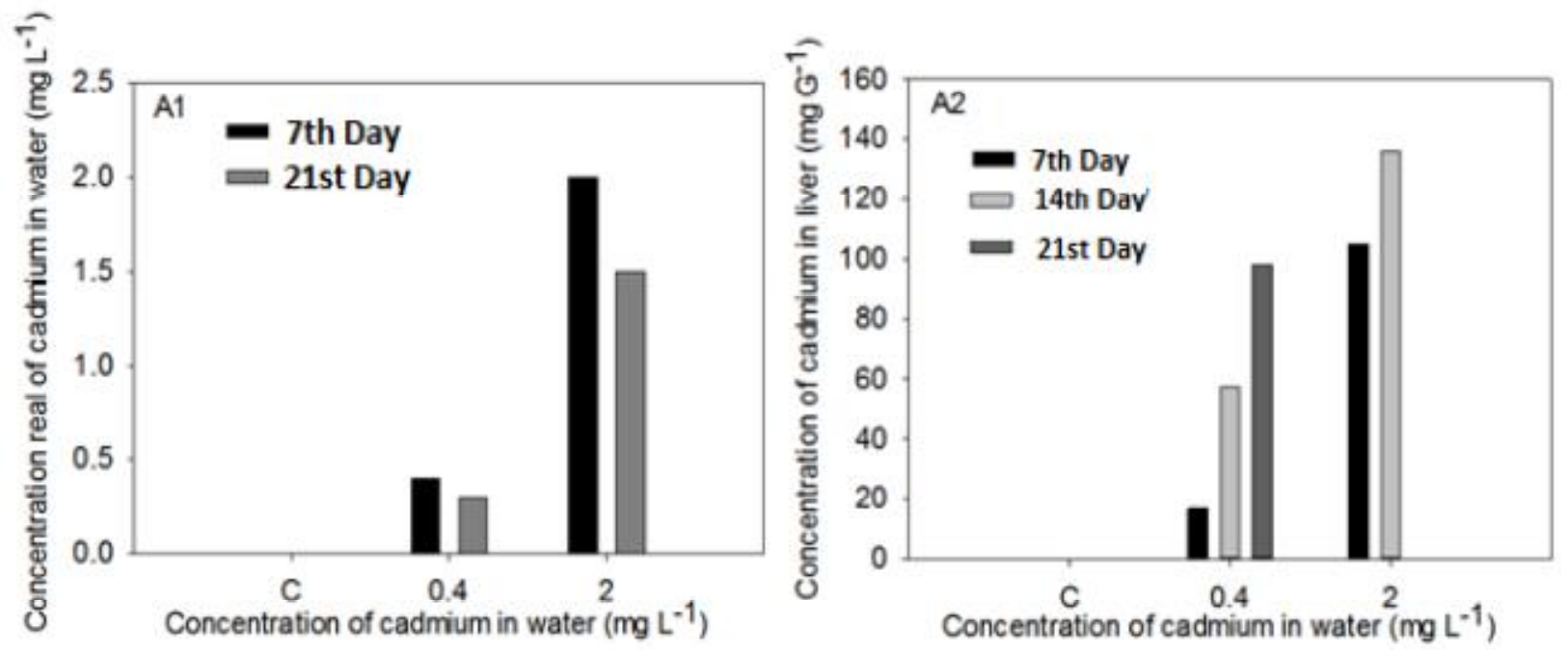

Fig. 1: A1 - Mean values of the actual concentration of cadmium in the Oreochromis niloticus in water. $\mathrm{A} 2$ - Concentration of cadmium in livers (mean, $\mathrm{n}=4$ per treatment) of juveniles of $O$.niloticus exposed to clean water and at concentrations of 0.4 and $2 \mathrm{mg} \mathrm{L}^{-1}$ and in clean water every 7 days of exposure (ANOVA-F5.2 = 11.6, $\mathrm{p}=0.013$ ) (Dunnett's test, $\mathrm{p}<0.05$ ); (C): control.

The bioaccumulation factor of cadmium in O. niloticus exposed to clean water, 0.4 and 2 $\mathrm{mg} \mathrm{L}^{-1}$ was $0,41.8$ and 53 at 7 day, respectively whereas in those exposed to water and $0.4 \mathrm{mg} \mathrm{L}^{-1}$ for 21 days the values were 0 and 327.3, respectively. There were no samples from individuals exposed to $2 \mathrm{mg} \mathrm{L}^{-1}$ in the last week of exposure due to the individual deaths.

\section{Hematologic Analysis and Leukogram:}

The qualitative evaluation of the blood cells in the smears of control fish allowed the characterization of both erythrocytes and leukocytes from juveniles of Oreochromis niloticus. The cells found in this species were: erythrocytes, lymphocytes, monocytes, neutrophils, eosinophils, basophils and special granulocytic cells (CGE). The red blood cells of $O$. niloticus are oval and central nuclei and were the most frequent cells in the blood of these animals. Thrombocytes were small smaller cells, with the nucleus occupying most of the cell and had varied morphology, with the nucleus occupying most of the cell, probably due to its functions of hemostasis and phagocytosis in fish, in inflammatory regions. Lymphocytes, in turn, were spherical cells, with varying sizes and intense cytoplasmic basophilia. Monocytes were large cells, with an eccentric nucleus, cytoplasmic basophilia, and a variable amount of cytoplasm. Neutrophils were rounded, with a central horseshoe nucleus oval, and cytoplasm basophilic of the neutrophils when stained exhibited typical neutrophilic granules. Eosinophils were also rounded cells, however they were characterized by the presence of coarse cytoplasmic granules that cover the nucleus and cytoplasmic acidophilia. The basophils resemble eosinophils with rounded - shape and coarse cytoplasmic granules. CGE was a rounded cell with a central nucleus of varied size, abundant cytoplasm with presence of clear granules and its interior transparent in it. In the morphological characterization of leukocytes from both treatments exposed to cadmium, lymphocytes, neutrophils and monocytes were identified in different stages of maturation and 
neutrophilic anisocytosis in relation to control fish.

Regarding leukogram, a quantitative analysis of white cells established a ratio of 38 leukocytes to 1000 red blood cells (Table 2). The observed leukocyte frequency is in Table 2. The comparative analysis of weekly leukogams identified a concentrationdependent immune response among individuals exposed to cadmium, with significant lymphocytosis in fish of 0.4 and 2 $\mathrm{mgL}^{-1}$ and neutrophilia and thrombophilia in 2 $\mathrm{mg} \mathrm{L}^{-1}$ at 14 days of exposure. In addition, moderate thrombophilia, increased monocytes and CGEs in fish exposed to $0.4 \mathrm{mg}$ $\mathrm{L}^{-1}$ and neutrophilia, thrombopenia and increased CGEs were also identified in fish exposed to $2 \mathrm{mg} \mathrm{L}^{-1}$ relative to the control. Lymphocytosis and significant neutropenia were noticed among individuals exposed to 2 $\mathrm{mg} \mathrm{L}^{-1}$ relative to the control at 21 days. In the analysis performed in 21 days it was not possible to evaluate the fish of the concentration $2 \mathrm{mg} \mathrm{L}^{-1}$ because they had already died. The median values of the leukocytes have been shown in Table 2 and Fig. 2.

\section{Hepatosomatic Index (HSI):}

The mean HSI values did not show a statistically significant difference between the exposed fish 0.4, 2.0, 4.1 and $7.5 \mathrm{mg} \mathrm{L}^{-1}$ and the control during the 21 days of exposure. The HSI mean values of control subjects and those exposed to 0.4 and $2.0, \mathrm{mg} \mathrm{L}^{-1}$ were 0.16 , 1.33 and $1.43(\mathrm{~g})$, respectively $(\mathrm{KW}-\mathrm{H} 4=0.54$, $\mathrm{p}=0.96$ ) (Fig. 3).

Histopathology of the liver, pancreas and histopathological alteration index:

The histopathological findings of the fish liver, control group and those exposed to the concentrations 0.4 and $2 \mathrm{mg} \mathrm{L}^{-1}$, showed similar structure to those observed in other teleosts. The normal hepatic parenchyma showed hepatocytes with polygonal shape, rounded nucleus and granular cytoplasm. In this species, it was also possible to verify the exocrine pancreas with its polygonal cells with normal conformation, several granules of secretion inside the cytoplasm and with prominent and rounded central nucleus and a blood vessel in central position of the organ. These cells presented basophilia when stained with hematoxylin and eosin (Fig. 4 A).

At the concentrations 0.4 and $2 \mathrm{mg} \mathrm{L}^{-1}$ slight changes were observed (1) - nucleus lateral position due to the pressure exerted by large cytoplasmic vacuoles reaching the majority of the parenchyma, infiltration of leukocytes in regions of probable inflammations or allergies; (2) hepatocytes and cells of the exocrine pancreas in the process of cell cytoplasm degeneration, retilinization of sinusoidal vessels and hepatic parenchyma (cords) with disposition of hepatocytes in cords and severe alterations and (3) areas of necrosis of hepatocytes or pancreatic exocrine cells and increased numbers of cells with tumor formation (Table 1). Analysis of the specimens exposed to 0.4 and $2 \mathrm{mg} \mathrm{L}^{-1}$ for 7 days showed that 100\% of subjects had mild (1) and moderate (2) alterations, and in $25 \%$ of severe alterations were observed (3), such as necrosis of hepatocytes and pancreatic cells. The most common of the severe alterations was degeneration of hepatocytes in the same area, characterizing a focal necrosis (Fig. 4C) and the presence of exocrine pancreas at an advanced stage of degeneration in $0.4 \mathrm{mg} \mathrm{L}^{-1}$ (86\%) and in $2 \mathrm{mg} \mathrm{L}^{-1}$ (95\%).

The specimens analyzed on the 14 th day 

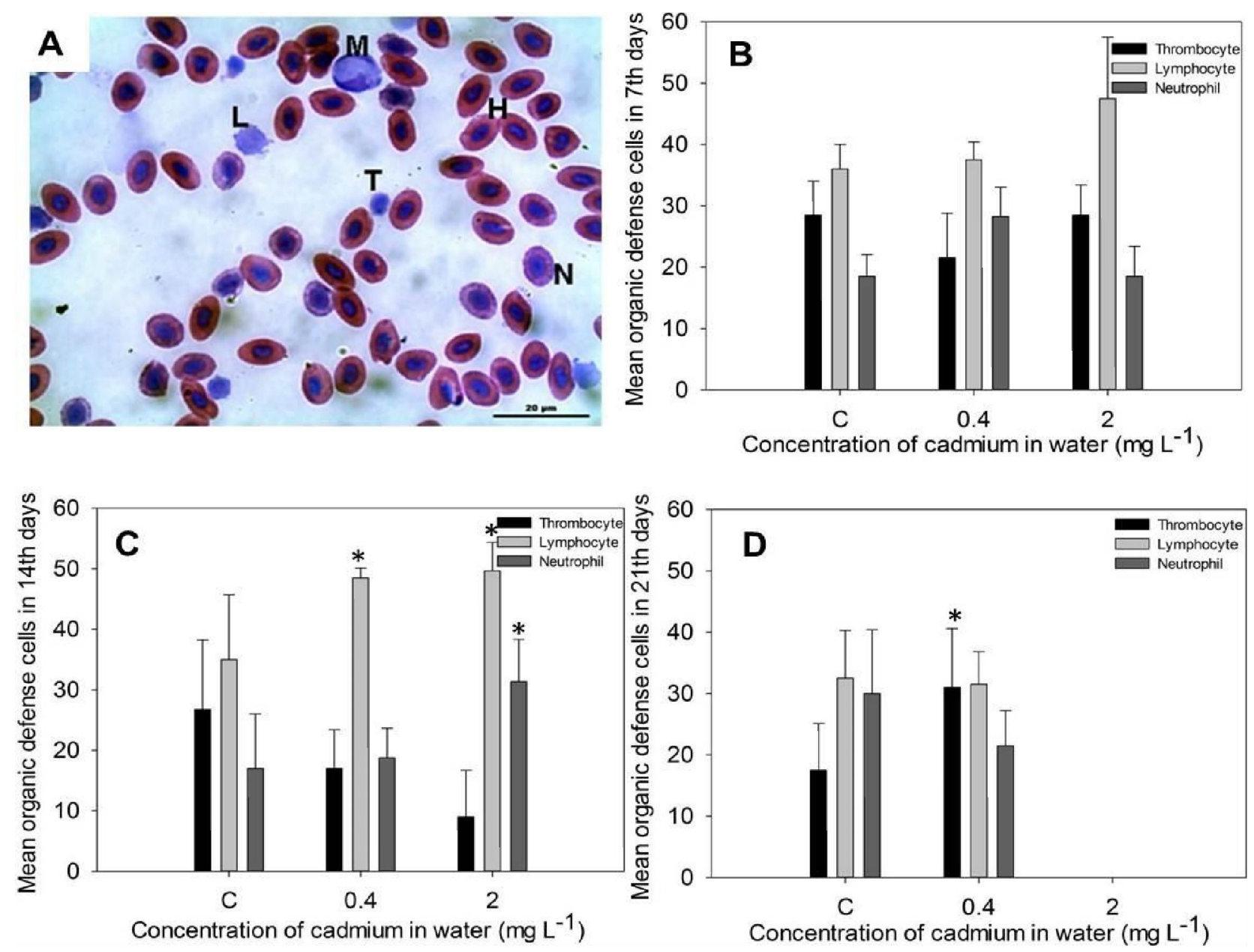

Fig. 2: Leukocyte alterations observed in blood of Oreochromis niloticus. A - Leukocytes in normal fish blood HE (400X), L: lymphocytes, M: monocytes, H: red blood cells, T: thrombocytes, N: neutrophils; B-C-D- Mean values of the leukocytes in the 0 . niloticus in 7,14 and 21 days, respectively after exposure of the clean water (control) and at concentrations of 0.4 and $2.0 \mathrm{mg} \mathrm{Cd} \mathrm{L}^{-1} .{ }^{*}$ Statistically different relative to control.

of exposure showed changes mainly of mild severity (1 cytoplasmic vacuolization) and moderate $(2$ aggregation of phagocytic macrophages and leukocyte infiltrate) in individuals exposed to all concentrations. It was verified that $100 \%$ of the individuals exposed to $0.4 \mathrm{mg} \mathrm{L}^{-1}$ presented the unstructured pancreas with loss of cell delimitation and cytoplasmic granulation. of the individuals exposed to $2 \mathrm{mg} \mathrm{L}^{-1}, 50 \%$ had more than one hyperplastic cell focus, probably a sign of the onset of tumors in the same parenchyma. This severe change may have been potentiated by the concentration of cadmium in the liver after this exposure period. On the $21^{\text {st }}$ day, the frequency of severe changes in $O$. niloticus species was dose-dependent $0.4 \mathrm{mg} \mathrm{L}^{-1}$ and $2 \mathrm{mg} \mathrm{L}^{-1}$ relative to the exposure period. The presence of death cell areas in the hepatic parenchyma characterizing an area of necrosis, with degenerating pancreas and the large number of cells atrophied with the strongly condensed chromatin (Fig. 4D) showed the difficulty in the organ repair capacity. 
Table 1: Frequencies of histopathological alterations (\%) observed in the liver of Oreochromis niloticus during exposure to 0.4 and $2 \mathrm{mg} \mathrm{L}^{-1}$ of cadmium at days 7, 14 and 21

\begin{tabular}{|c|c|c|c|c|c|c|c|c|c|}
\hline \multirow[b]{2}{*}{ Alteration } & \multicolumn{3}{|c|}{ 7th day } & \multicolumn{3}{|c|}{ 14th day } & \multicolumn{3}{|c|}{ 21st day } \\
\hline & $\mathbf{C}$ & $\begin{array}{c}0.4 \\
\mathrm{mgL}^{-1}\end{array}$ & $\begin{array}{c}2 \\
\mathbf{m g L}^{-1}\end{array}$ & $\mathbf{C}$ & $\begin{array}{c}0.4 \\
\mathrm{mgL}^{-1} \\
\end{array}$ & $\begin{array}{c}2 \\
\mathbf{m g L}^{-1}\end{array}$ & $\mathbf{C}$ & $\begin{array}{c}0.4 \\
\mathrm{mgL}^{-1}\end{array}$ & $\begin{array}{c}2 \\
\mathbf{m g L}^{-1}\end{array}$ \\
\hline $\begin{array}{l}\text { Melano macrophage } \\
\text { center }\end{array}$ & 50 & 50 & 50 & 50 & 67 & 50 & 50 & 0 & 0 \\
\hline Vacuolated cytoplasm & 75 & 100 & 50 & 25 & 67 & 0 & 100 & 50 & 0 \\
\hline $\begin{array}{l}\text { Irregular form of the } \\
\text { hepatocytes }\end{array}$ & 75 & 100 & 50 & 25 & 100 & 0 & 50 & 25 & 0 \\
\hline $\begin{array}{l}\text { Pancreas irregular } \\
\text { form }\end{array}$ & 75 & 100 & 50 & 25 & 100 & 50 & 50 & 100 & 0 \\
\hline Lipofucsine granules & 25 & 25 & 0 & 25 & 0 & 0 & 50 & 0 & 0 \\
\hline Celularhipertrophy & 0 & 0 & 0 & 25 & 0 & 0 & 0 & 0 & 0 \\
\hline $\begin{array}{l}\text { Lateral position of the } \\
\text { nucleus }\end{array}$ & 25 & 0 & 0 & 25 & 0 & 0 & 0 & 25 & 0 \\
\hline Leukocyte infiltration & 75 & 75 & 50 & 50 & 100 & 50 & 100 & 25 & 0 \\
\hline Cell degeneration & 100 & 75 & 0 & 25 & 67 & 0 & 50 & 50 & 0 \\
\hline $\begin{array}{l}\text { Pancreas cell } \\
\text { degeneration }\end{array}$ & 50 & 75 & 100 & 50 & 33 & 100 & 100 & 100 & 0 \\
\hline Pyknotic nuclei & 50 & 100 & 50 & 75 & 67 & 100 & 100 & 75 & 0 \\
\hline Rectilinear vessels & 50 & 75 & 50 & 75 & 67 & 100 & 50 & 0 & 0 \\
\hline $\begin{array}{l}\text { Rectilinear } \\
\text { parenchyma in cords }\end{array}$ & 75 & 75 & 50 & 75 & 100 & 100 & 100 & 75 & 0 \\
\hline Focal necrosis & 25 & 25 & 0 & 0 & 0 & 0 & 0 & 25 & 0 \\
\hline Hyperplasia/Tumor & 0 & 0 & 0 & 0 & 0 & 50 & 0 & 0 & 0 \\
\hline
\end{tabular}


Table 2: Mean \pm standard deviation of organic blood cells of tilapia Oreochromis niloticus exposed to cadmium

\begin{tabular}{|c|c|c|c|c|c|c|c|c|c|c|c|c|c|c|c|c|c|c|}
\hline \multirow{3}{*}{$\begin{array}{c}\text { Organic } \\
\text { defense blood } \\
\text { cells }(\%)\end{array}$} & \multicolumn{6}{|c|}{7 days exp osure $\left(\mathrm{mg} \mathrm{Cd}^{-1} \mathrm{~L}\right)$} & \multicolumn{6}{|c|}{14 days exp osure $\left(\mathrm{mg} \mathrm{Cd}^{-1} \mathrm{~L}\right)$} & \multicolumn{6}{|c|}{21 days exposure $\left(\mathrm{mg} \mathrm{Cd}^{-1} \mathrm{~L}\right)$} \\
\hline & \multicolumn{2}{|l|}{$\mathrm{C}$} & \multicolumn{2}{|c|}{0.4} & \multicolumn{2}{|l|}{2} & \multicolumn{2}{|l|}{$\mathrm{C}$} & \multicolumn{2}{|c|}{0.4} & \multicolumn{2}{|l|}{2} & \multicolumn{2}{|l|}{$\mathrm{C}$} & \multicolumn{2}{|c|}{0.4} & \multicolumn{2}{|c|}{2} \\
\hline & $\begin{array}{l}\text { Mean } \\
\text { Stand. } \\
\text { Dev. }\end{array}$ & $\begin{array}{l}\text { Range of } \\
\text { variation }\end{array}$ & $\begin{array}{c}\text { Mean } \\
\text { Stand. Dev. }\end{array}$ & $\begin{array}{l}\text { Range of } \\
\text { variation }\end{array}$ & $\begin{array}{c}\text { Mean } \\
\text { Stand. Dev. }\end{array}$ & $\begin{array}{l}\text { Range of } \\
\text { variation }\end{array}$ & $\begin{array}{c}\text { Mean } \\
\text { Stand. Dev. }\end{array}$ & $\begin{array}{l}\text { Range of } \\
\text { variation }\end{array}$ & $\begin{array}{c}\text { Mean } \\
\text { Stand. } \\
\text { Dev. }\end{array}$ & $\begin{array}{l}\text { Range of } \\
\text { variation }\end{array}$ & $\begin{array}{l}\text { Mean } \\
\text { Stand. } \\
\text { Dev. }\end{array}$ & $\begin{array}{l}\text { Range of } \\
\text { variation }\end{array}$ & $\begin{array}{c}\text { Mean } \\
\text { Stand. Dev. }\end{array}$ & $\begin{array}{l}\text { Range of } \\
\text { variation }\end{array}$ & $\begin{array}{c}\text { Mean } \\
\text { Stand. } \\
\text { Dev. }\end{array}$ & $\begin{array}{l}\text { Range of } \\
\text { variation }\end{array}$ & $\begin{array}{l}\text { Mean } \\
\text { Stand. } \\
\text { Dev. }\end{array}$ & $\begin{array}{l}\text { Range of } \\
\text { variation }\end{array}$ \\
\hline Thrombocyte & $28.5 \pm 7.5$ & $23-34$ & $21.5^{\mathrm{a}} \pm 14.7$ & $7-40$ & $28.5^{2} \pm 4.9$ & $25-32$ & $26.8 \pm 22.9$ & $4-54$ & $17.0^{2} \pm 6.4$ & $7-34$ & $9.0^{\mathrm{a}} \pm 7.7$ & $4-17$ & $17.5 \pm 7.6$ & $4-17$ & $40.0^{b} \pm 9.6$ & $15-58$ & -- & -- \\
\hline Lymphocyte & $36.0 \pm 4.0$ & $32-40$ & $37.5^{\mathrm{a}} \pm 2.9$ & $30-44$ & $47.5^{\mathrm{a}} \pm 10.0$ & $37-58$ & $35.0 \pm 10.7$ & $37-52$ & $48.5^{b} \pm 1.6$ & $44-51$ & $49.7^{b} \pm 4.7$ & $46-55$ & $32.5 \pm 7.8$ & $46-55$ & $31.5^{\mathrm{a}} \pm 5.3$ & $20-58$ & -- & -- \\
\hline Neutrophil & $26.5 \pm 3.5$ & $23-30$ & $28.3^{2} \pm 4.8$ & $20-37$ & $18.5^{\mathrm{a}} \pm 4.9$ & $4-33$ & $17.0 \pm 9.0$ & $7-44$ & $18.8^{\mathrm{a}} \pm 4.9$ & $11-33$ & $31.3^{b} \pm 7.0$ & $25-40$ & $35.0 \pm 10.4$ & $25-40$ & $21.5^{\mathrm{a}} \pm 5.7$ & $6-39$ & -- & -- \\
\hline CGE & $1.5 \pm 1.5$ & $0-3$ & $2.8^{\mathrm{a}} \pm 0.8$ & $1-5$ & $1.0^{\mathrm{a}} \pm 0.7$ & $1-1$ & $1.3 \pm 0.6$ & $0-3$ & $6.8^{2} \pm 5.4$ & $0-23$ & $4.0^{\mathrm{a}} \pm 1.2$ & $1-6$ & $2.3 \pm 0.6$ & $1-6$ & $1.5^{\mathrm{a}} \pm 0.6$ & $1-4$ & -- & -- \\
\hline M onocyte & $3.0 \pm 0.0$ & 3.00 & $7.3^{\mathrm{a}} \pm 1.1$ & $5-40$ & $1.5^{\mathrm{a}} \pm 0.0$ & $1-2$ & $1.8 \pm 0.8$ & $0-4$ & $6.5^{\mathrm{a}} \pm 1.6$ & $2-9$ & $4.7^{\mathrm{a}} \pm 0.0$ & $4-6$ & $4.8 \pm 1.8$ & $4-6$ & $4.3^{\mathrm{a}} \pm 3.3$ & $2-10$ & -- & -- \\
\hline Eosinophil & $0.3 \pm 0.2$ & $0-4$ & $2.0^{2} \pm 0.7$ & $1-4$ & $2.0^{\mathrm{a}} \pm 0.0$ & $2-2$ & $0.3 \pm 0.2$ & $0-1$ & $0.8^{a} \pm 0.5$ & $0-2$ & $1.0^{\mathrm{a}} \pm 0.6$ & $1-1$ & $1.0 \pm 0.8$ & $1-1$ & $0.8^{2} \pm 0.9$ & $0-2$ & -- & -- \\
\hline Basophile & $0.5 \pm 0.2$ & $1-4$ & $0.8^{a} \pm 0.3$ & $0-1$ & $1.0^{\mathrm{a}} \pm 0.0$ & $1-1$ & $0.5 \pm 0.3$ & $0-1$ & $1.8^{\mathrm{a}} \pm 1.1$ & $0-5$ & $0.3^{\mathrm{a}} \pm 2.6$ & $0-1$ & $2.0^{\circ} \pm 0.4$ & $0-1$ & $0.5^{\mathrm{a}} \pm 1.0$ & $1-3$ & -- & -- \\
\hline
\end{tabular}

a statistically not significant from control; ${ }^{\mathrm{b}}$ statistically significant from control 


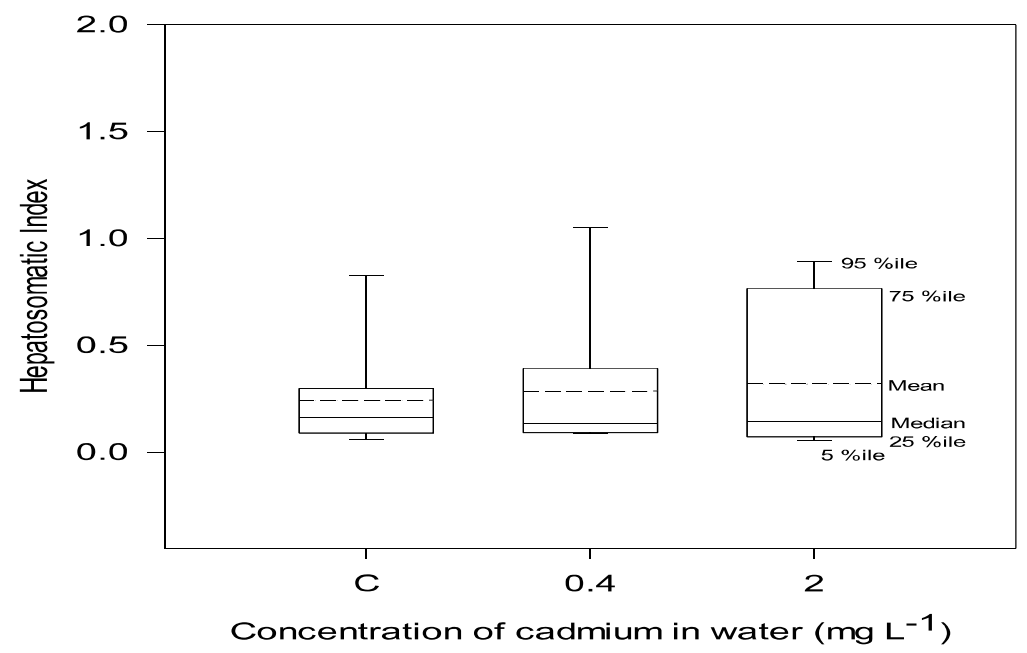

Fig. 3: Hepatosomatic index of juveniles of Oreochromis niloticus (median, $\mathrm{n}=24$ per treatment) exposed to clean water and concentrations of 0.4 and $2 \mathrm{mg} \mathrm{L}^{-1}$ for 21 days of experiment (KW-H4 =0.54, $\left.\mathrm{p}=0.96\right)$; (C): control

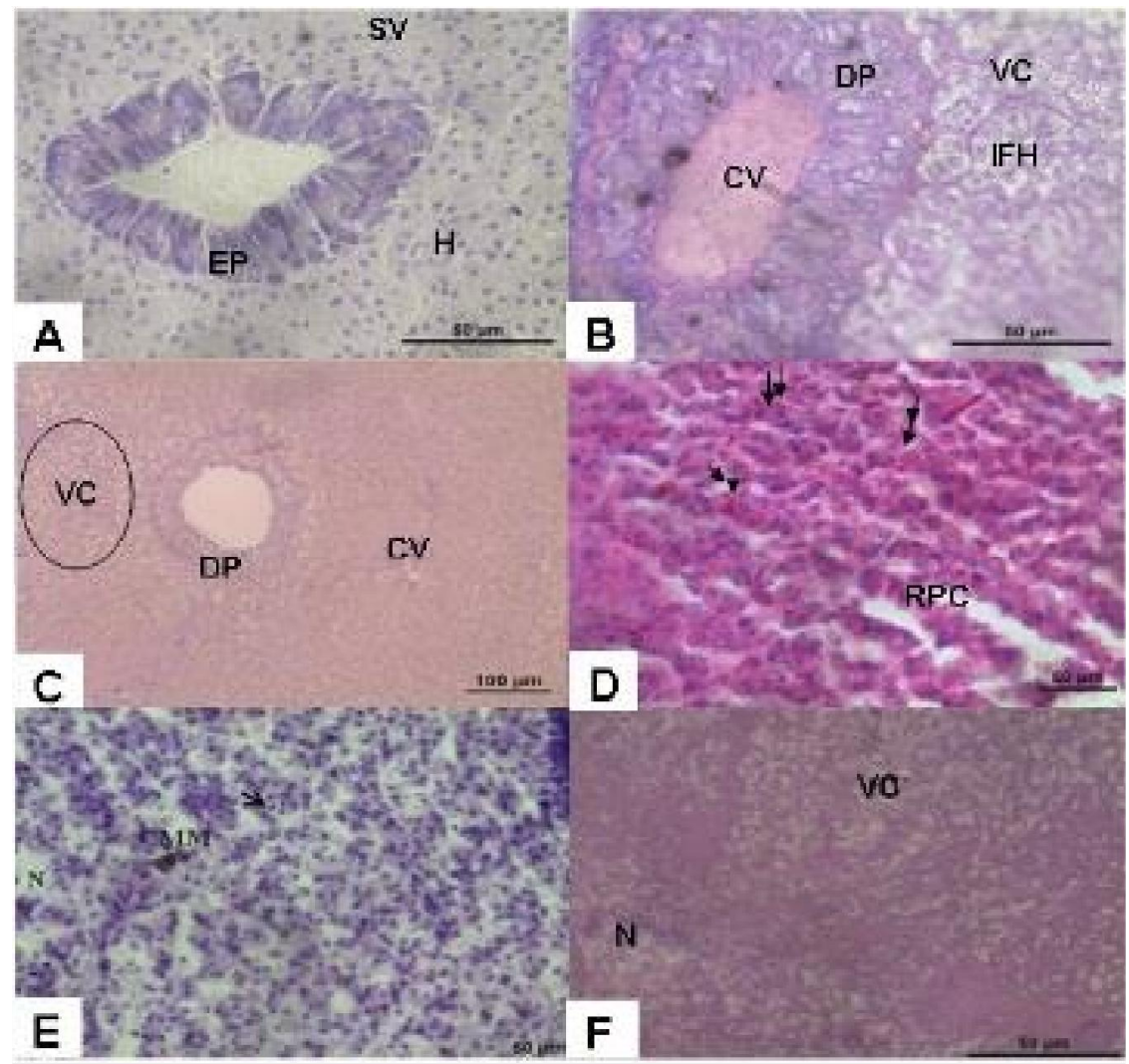

Fig. 4: Histopathological changes observed in liver and pancreas of Oreochromis niloticus. A) normal liver HE (400X); B-C-D) Liver with moderate alterations in the parenchyma and exocrine pancreas HE (400X and 100X); E-F) Liver with severe changes HE (400X). SV - Blood vessel, H - Hepatocytes, EP - Exocrine pancreas, DP - degenerating pancreas, CV - Vacuolated hepatocytes, FIH - Irregular form of hepatocytes, CV - Blood vessel congestion, CMM Melano macrophagic center, N - Necrosis, Arrow - Pycnotic nuclei, Double arrow - Blood cell infiltration, RPC Straight parenchyma in cord, VC - Vacuolated hepatocytes 


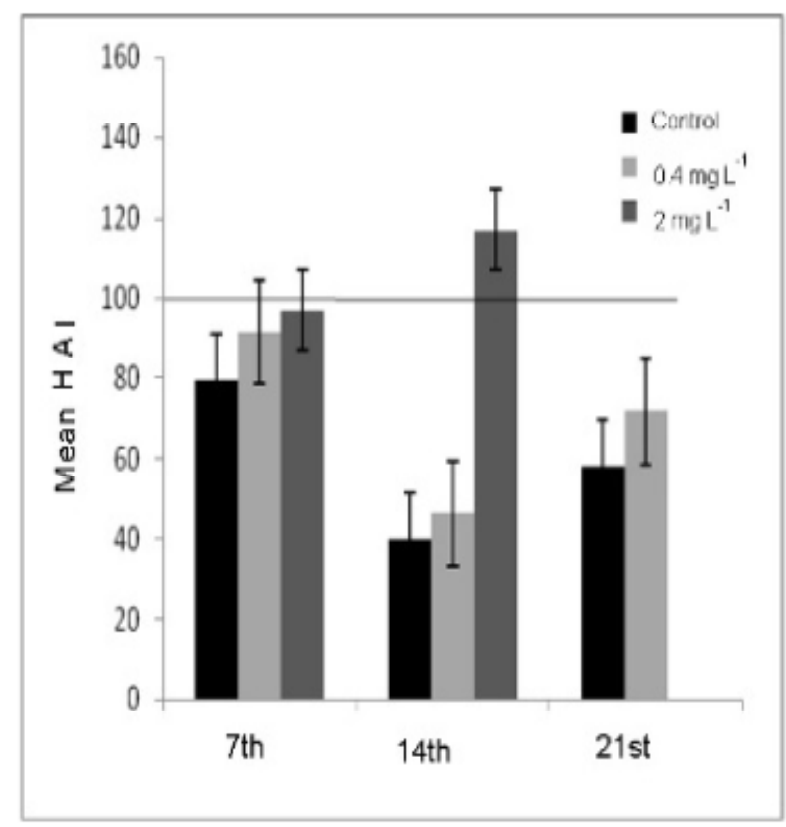

Fig. 5: Mean of histopathological alterations index (HAI) observed in the liver of Oreochromis niloticus (mean \pm standard deviation, $\mathrm{n}=4$ per treatment) exposed to clean water and to concentrations of 0.4 and $2 \mathrm{mg} \mathrm{L}^{-1}$ every 7 days of exposure exhibition; (C): control
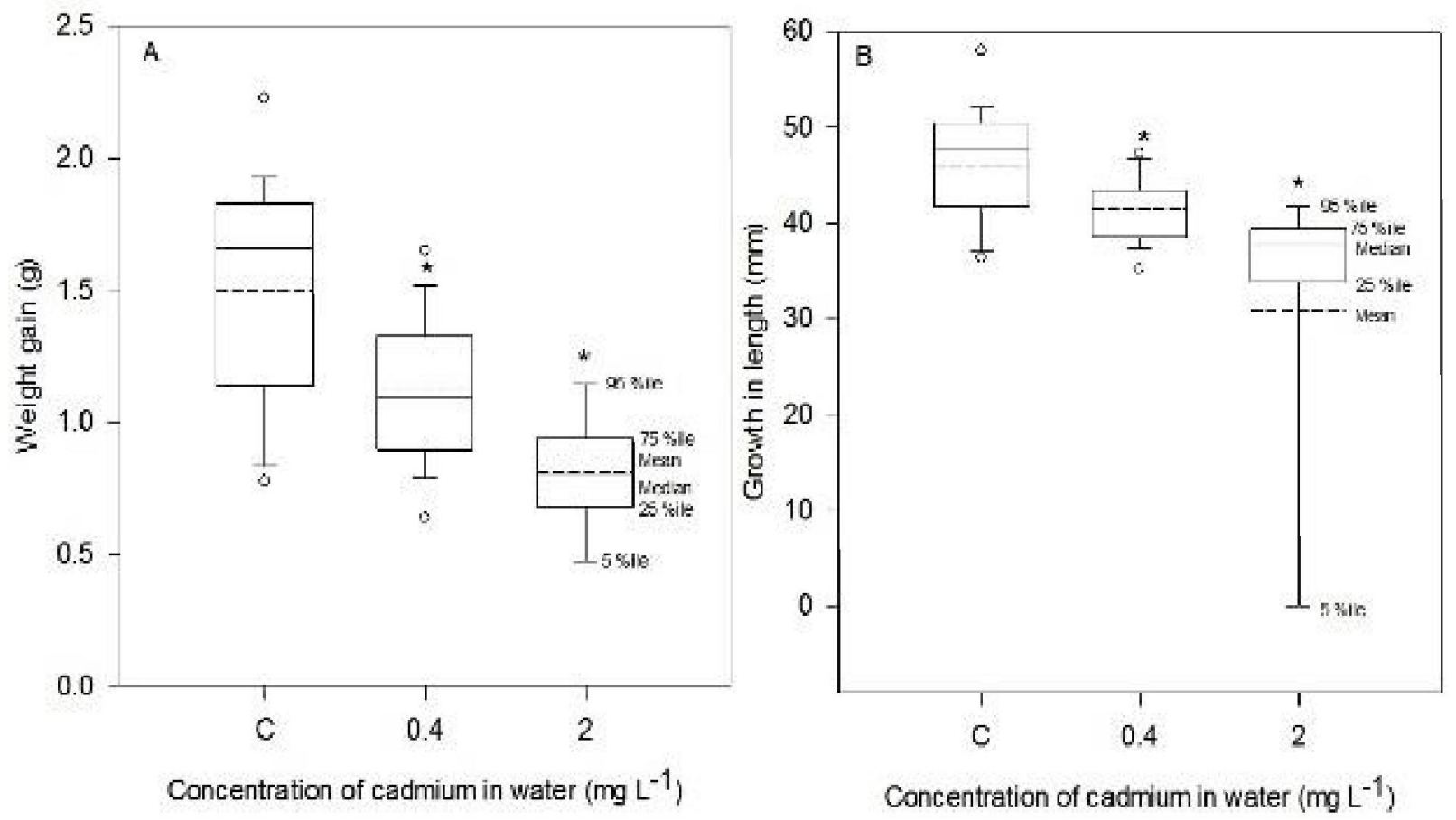

Fig. 6: Productive performance of juveniles of Oreochromis niloticus. A - Productive performance in relation to weight gain $(\mathrm{g})$ and $\mathrm{B}$ - related to the growth $(\mathrm{mm})$ in length of $O$. niloticus (median, $\mathrm{n}=24$ per treatment) exposed to clean water and to concentrations of 0.4 and $2 \mathrm{mg} \mathrm{L}^{-1}$ during 21 days of experiment. (A- KW-H2 $=23.8, \mathrm{p}=0.001$ ) (Dunn Test, $\mathrm{p}<0.05$ ); (B $-\mathrm{KW}-\mathrm{H} 2=22,5, \mathrm{p}=0.001$ ) (Dunn Test, $\mathrm{p}<0.05$ ) (C): control; ${ }^{*}$ ): statistically different relative to control. 
Data from the semi-quantitative HAI analysis of the control samples, 0.4 and $2 \mathrm{mg}$ $\mathrm{L}^{-1}$ on the 7 th day of exposure (HAI $=91.5$ and 97.0) suggest that the individuals analyzed relative to control had an organ with a high frequency of moderate lesions and severity that increased the rate of change, classifying the organ as having serious structural damage considered irreparable (Fig. 5).

\section{Productive performance and growth:}

The median values of the weight gain in control and exposed fish to 0.4 and $2 \mathrm{mg} \mathrm{L}^{-1}$ cadmium were: $1.65,1.09,0.81 \mathrm{~g}$, respectively. A significant reduction of $34 \%$ and $51 \%$ was observed between the weight medians gain of 0 . niloticus exposed to 0.4 and $2 \mathrm{mg} \mathrm{L}^{-1}$ in relation to the control $(\mathrm{KW}-\mathrm{H} 2=23.8, \mathrm{p}=$ 0.001; Dunn p <0.05) (Fig. 6A). For growth, the median values of the total length were 47.8, 41.6, $37.8 \mathrm{~mm}$, respectively. A significant reduction of $13 \%$ and $21 \%$ in the length of subjects exposed to 0.4 and $2 \mathrm{mg} \mathrm{L}^{-1}$ was also observed in relation to the control $(\mathrm{KW}-\mathrm{H} 2=$ 22.5, $\mathrm{p}=0.001$, Dunn $\mathrm{p}<0.05$ ) (Fig. 6B).

\section{Discussion}

Cadmium has high toxicity to organisms and is capable of developing lethal and sublethal effects on the aquatic animals health and ecosystems. The 0 . niloticus juveniles exposed to cadmium presented high bioaccumulation in the liver and developed vacuoles with lipids accumulation, liver and pancreas degenerations and other histopathological alterations in the hepatic tissue, besides presenting reductive effects on the physiological aspects of the growth and weight gain in fish exposed to 0.4 and $2 \mathrm{mg} \mathrm{L}^{-1}$. These effects make these individuals susceptible to disease development and may compromise the juveniles recruitment into adults.

It was possible to observe that juveniles of O. niloticus showed significant sensitivity to the xenobiotic. In this study the lethal effect (96h-LC50) of the estimated cadmium for

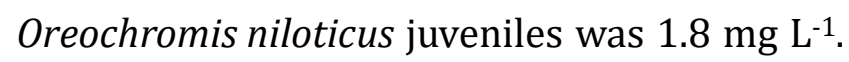
The lethal sensitivity of fish exposed to $96 \mathrm{~h}$ $\mathrm{LC}_{50}$ varies greatly, from $2.5 \mu \mathrm{g} \mathrm{\textrm {L } ^ { - 1 }}$ to the most sensitive species in larvae of Solea senegalensis exposed from 6.25 to $100 \mu \mathrm{g} \mathrm{L} \mathrm{L}^{-1}$ of this trace metal (Pavlaki et al., 2016), up to $2 \mathrm{mg} \mathrm{L}^{-1}$ for Catla catla exposed up to $5 \mathrm{mg} \mathrm{L}^{-1}$, where it was found that exposure to $2 \mathrm{mg} \mathrm{L}^{-1}$ already promoted mortality (Sobha et al., 2007). This suggests that the sensitivity of $O$. niloticus is intermediate among the other species. The lethal effect produces important information for comparisons of species survival in relation to the contaminant studied, but is insufficient to clarify the viability of these surviving individuals after contamination.

The morphological disorders in the blood leukocytes and thrombocytes can be used as a tool for prognostic assessment of the challenges that the fish are exposed the agents aggressors, causing anisocytosis, successive mitotic divisions producing new cells as a consequence of exposure to toxic agents (Satake et al., 2009). The data obtained in these studies have demonstrated the significance and importance of using the method of histopathological analysis in order to evaluate the occurrence of various types of changes in different species. The appearance of several types of alterations is probably related to the presence of various stressors in the studied environments. Also, in this study, these were observed causing morphological alterations in the defense cells. The 
morphological characterization of $O$. niloticus blood cells in this study made it possible to identify the specific blood components and the cytotoxic effects of cadmium on them. Changes in erythrocytes have not been identified since the $7^{\text {th }}$ day of study. In this study, leucogram suggested that the exposure of fish to cadmium induced a significant increase in defense cell at $14^{\text {th }}$ and $21^{\text {st }}$ days of exposure compromising the immune system and increasing vulnerability to diseases. Shifts in lymphocyte populations, as well as neutrophilia were seen in fish exposed for 2 weeks to $\mathrm{Cd}$ relative to control, and similar changes might occur in their activities with respect to cytokine formation or release by lymphocytes due to contamination. An intense thrombocytosis at $0.4 \mathrm{mg} \mathrm{L}^{-1}$ at 21 day, evidencing the likely phagocytic or coagulant activity of these components in inflammatory areas on the body of the individuals, as reported by Tavares Dias and Moraes (2003). Thus, it was possible to infer that the exposure period of 7 days at a dosage of $0.4 \mathrm{mg} \mathrm{L}^{-1}$ and 2 $\mathrm{mg} \mathrm{L}^{-1}$ was not enough to generate a significant immune response, although there were many lymphocytes in $2 \mathrm{mg} \mathrm{L}^{-1}$. It was not possible to verify in the study the mechanisms that caused the elevation or reduction of each specific cellular component, only being observed the generation of the immunological response due to the intoxication by cadmium.

Leukocytes are specialized cells responsible for a variety of immune response activity in the body and changes in these cells caused by environmental factors can promote serious consequences for the body's immune function or in the development of persistent diseases, and growth reduce (Mateus et al., 2017). It has been reported that exposure to this metal affects the levels of circulating leukocytes in tissues and promotes the condensation of the leukocyte chromatin, resulting in apoptosis, specific fragmentation in the DNA and death of these cells in longterm exposures (Vazzana et al., 2014). In another study with fish exposed to lead, Adeyemo et al. (2010) found a reduction in lymphocytes similar to that observed in this study, where a significant increase in lymphocyte levels was detected after cadmium exposure, probably due to stimulation of the immune system; followed later by a decrease in these cells and other white blood cells in long-term exposure due to lesions in the immune system.

Cadmium bioaccumulation in the liver was observed at concentrations 0.4 and $2 \mathrm{mg} \mathrm{L}^{-1}$ during the 21 days. The mean values of this bioaccumulation in the juveniles, on the 7 th and 21st day, showed that the increase of the internal concentration in the fish liver was dose- dependent in relation to the time of exposure. The bioaccumulation and the BCF (BCF >1) of cadmium in the liver of exposed fish evidenced the retention capacity of this metal in this organ and showed how the detoxification and elimination capacity became compromised throughout exposure time.

Several studies with fishes have shown that the bioaccumulation of this metal in the liver has promoted a significant increase in the induction of antioxidant defence enzymes, such as reduced gluthatione (GSH) and superoxide dismutase (SOD), which act in the biotransformation and help in contaminants elimination in oxidative stress situation in this organ. This fact was observed in adults of Danio rerio exposed to $1 \mu \mathrm{M}$ of cadmium for 30 days, which bioaccumulated $17.42 \mathrm{mg} \mathrm{kg}^{-1}$ in the liver and showed increased glutathione S-transferase GST activity and a significant 
increase in SOD induction (Duan et al. 2017). Rhamdia quelen exposed to $100 \mu \mathrm{g} \mathrm{L}^{-1}$, which had a bioaccumulation mean of $12.7 \mu \mathrm{g} \mathrm{g}^{-1}$ in the liver and also showed increased activity of biotransformation enzymes GST, GSH and glutathione peroxidase GPx that act in the metabolization of this compound in the liver (Pereira et al., 2016). Although the metabolic activity of these biotransformation enzymes was not a parameter evaluated in this study, but based on the results and knowledge about the liver as an important organ of storage and detoxification of contaminant, the bioaccumulation of this pollutant probably altered the metabolic and homeostatic conditions in the individuals of this species, leading to the triggering of changes in liver morphology and function, such as the development of a high frequency of moderate and severe liver alterations in exposed individuals. This bioaccumulation makes a detrimental condition worrying since this metal is not an essential element in the biological functions of organisms, and that even at low concentrations can cause mortality or trigger changes.

In addition, in relation to effects in the liver the hepatocyte vacuolization was a moderate alteration observed in $75 \%$ of the individuals, and even being classified as a mild severity alteration, the high frequency of this alteration was considered as pathological, since there is an increase in vacuolated cells number, which may promote a condition of non-alcoholic steatosis in individuals. Vacuolization was generally associated with other moderate-grade changes such as the presence of irregular or pyknotic nuclei in hepatocytes, similar to that observed by Samanta et al. (2018).
The cytoplasmic vacuolations associated with lipid storage within the vacuole can represent a normal hepatic condition (Fanta et al., 2003), or occur as an indicator of stress at high energy demand or the presence of some chemical in the organ (Kumar et al., 2007). The development of high vacuolization in hepatocytes was also found in adults of Danio rerio exposed to $1 \mathrm{mg} \mathrm{L}^{-1} \mathrm{CdO}$ (Balmuri et al., 2017) and according to van Dyk et al. (2007) the presence of this pathology in $O$. mossambicus exposed to $0.018 \mathrm{mg} \mathrm{L}^{-1}$ may be indicative of the time of exposure to the metal, being more frequent in short period exposures.

Development of severe alterations such as extensive liver parenchymal degeneration was observed in subjects exposed to $2 \mathrm{mg} \mathrm{L}^{-1}$ on day 14 and $0.4 \mathrm{mg} \mathrm{L}^{-1}$ of the substance on day 21 , with the development of two tumors in the early stages (50\%) and large foci of necrosis (25\%), respectively. The development of hepatocyte degeneration (necrosis) in Danio rerio exposed to $5 \mathrm{mg} \mathrm{L}^{-1} \mathrm{CdO}$, in addition to vacuolization and hepatocyte atrophy in some hepatic lobes were also verified by Balmuri et al. (2017) and Kaoud and El-Dahshan (2010) who observed foci of hepatocytes necrosis and pycnotic nuclei. Most of the alterations in hepatic parenchyma in $O$. niloticus may be considered due be the result of the detoxification action of the organ.

The HAI results corroborate the high frequency of moderate and severe alterations in the liver due to the increase in the occurrence of severe histopathological alterations observed in individuals with a concentration of 0.4 and $2 \mathrm{mg} \mathrm{L}^{-1}$. The index reflected the worsening of the lesion at more advanced stages of severity in 
individuals exposed to $2 \mathrm{mg} \mathrm{L}^{-1}$, evidencing that the exposure time to the trace metal in this study was continuously promoting an exhaustion condition in the organ. On the other hand, the 0.4 concentration at 7 days promoted in the organ an alarm condition, which progressively led to a chronic adaptive response. In addition to the relevance of the severe alterations, the occurrence of a high frequency of moderate alterations can lead the organ to an exhaustion condition, and, thus, situations of prolonged exposure to cadmium, may compromise the morphology and functionality of this organ and bring individuals to death.

The histopathological changes observed as a function of the bioaccumulation in $O$. niloticus liver resulted in the occurrence of changes in its physiology, observed through the HSI morphometric index and the body growth assessment (CT). The HSI value may indicate possible liver diseases such as atrophy or hepatomegaly, since they may indicate metabolic conditions in fish, for example, increased levels of HSI may be associated with detoxification activities in response to the presence of toxic compounds (Souza Pereira and Kuch, 2005). The results of

this study showed high HSI mean in individuals liver exposed to the xenobiotic in relation to the control, with the hepatomegaly development, which would probably be due to the high frequency of lipid vacuoles stored in the liver, in response to the bioaccumulation. This type of chronic alteration observed in the liver of the exposed individuals show that the contamination can promote an increase of mass and an accumulation of energetic sources in this organ due to the energetic demand to attend to the stress promoted by the metal.

Studies with fish exposed to cadmium observed a reduction in HSI levels and reduction of liver glycogen stores, such as Catla catla exposed to $4.5 \mathrm{mg} \mathrm{L}^{-1}$ of $\mathrm{CdCl}_{2}$ (Sobha et al., 2007) and Danio rerio exposed to $1 \mu \mathrm{M} \mathrm{Cd}$, which in addition to this reduction, observed hepatic atrophy promoted by exposure to the metal (Duan et al., 2017). Problems related to significant growth reduction were observed in fishes exposed to concentrations 0.4 and $2 \mathrm{mg} \mathrm{L}^{-1}$ that study and changes in this parameter have been considered as relevant indicators of fish health (Du Gas et al., 2017) as they can directly estimate the survival and recruitment of fish exposed to this contaminant in the aquatic environment. Lim et al. (2000) observed that in Ictalurus punctatus the essential elements substitution can promote a condition of hunger or starvation to the individual, which can lead to lack of appetite, reduction in consumption, reduction in feed conversion and, consequently, decrease of growth of fish. Chatterjee et al. (2006) reported that zinc ions influence nutrients assimilation and consequently the individuals food performance and that the substitution of this element by cadmium ions may also influence this process of assimilation. Thus, it is likely that the inhibition of growth and weight gain of these fish may be related to the contaminant action.

Sobha et al. (2007) reported that even if the individual exposed to this contaminant initially survives, the damage from progressive exposure, even in small doses, may manifest in later stages. Thus, the bioaccumulation of this 
substance in the liver was sufficiently toxic to cause changes in different biomarkers, causing alarm response in the preliminary exposure period and exhaustion responses over time, compromising liver morphology and homeostasis and growth of juveniles of this species.

\section{Conclusion}

It has been demonstrated in this study that cadmium bioaccumulation in the liver promotes hepatotoxicity and may influence the immune responses in Oreochromis niloticus individuals fish that has great economic importance for the aquaculture industry. These alterations in conjunction with the observed effects on growth reduction and fish weight gain exposed to concentrations of 0.4 and $2 \mathrm{mg} \mathrm{L}^{-1}$ showed the toxic potential of this heavy metal, as this contaminant may change the physiological conditions at initial life of a fish species and affect the recruitment of fish that has great economic importance in crops.

\section{Acknowledgement}

We would like to thank the Foundation for Research Support of the State of Bahia FAPESB for research funding and the University State of Santa Cruz - UESC for providing infrastructure and for technical support in the development of each stage of this work. The team of the Laboratory of Histology, Laboratory of Nutrition and Fish Feeding- AQUANUT, and technical supports from Laboratory of Analytical Chemistry at University State of Santa Cruz are also acknowledged.

\section{References}

Abraham J, Dowling K and Singarare F. (2017) Risk of post-fire metal mobilization into surface water resources: A review. Science Total Environment 599600: $1740-1755$.

Adeyemo OK, Adedeji 0 and Opffor CC. (2010) Blood lead level as biomarker of environmental lead pollution in feral and cultured African catfish (Clarias gariepinus). Nigerian Veterinary Journal 31: 139-147.

American Society of Ichthyologists and Herpetologists (ASIH) American Fisheries Society (AFS) American Institute of Fisheries Research Biologists (AIFRB). 1988. Guidelines for use of fishes in field research. Fisheries. 13,16-23.

Babich H, Shopsis C and Borenfreund E. (1986) In vitro cytotoxicity testing of aquatic pollutants (cadmium, copper, zinc, nickel) using established fish cell lines. Ecotoxicol. Environ. Safety 11: 91-99.

Babich H and Stotzky G. (1978) Effects of cadmium on the biota: influence of environmental factors. Adv. Applied Microbiology 23:55-117.

Barron MG. (1995) Bioaccumulation and bioconcentration in aquatic organisms. In: Handbook of Ecotoxicology, Eds. Hoffman, DJ, Rattner, BA, Burton GA Jr and Cairns J Jr. Boca Raton, Lewis Publishers. Cap. 30. 652-666.

Cao L, Huang W, Shan X, Xiao Z, Wang Q and Dou S. (2009) Cadmium toxicity to embryonic-larval development and survival in red sea bream Pagrus major. Ecotoxicol. Environ. Safety 72: 1966-1974.

Canadian Council on Animal Care. (1998) CCAC guidelines on: choosing an appropriate endpoint in experiments using animals for research, teaching and testing.

Canadian Council on Animal Care. (2005) CCAC Guidelines on: the care and use of fish in research, teaching and testing.

Cinier CD, Petit Ramel M, Faure R and Carin D. (1997) Cadmium bioaccumulation in carp (Cyprinus carpio) tissues during long-term high exposure: analysis by inductively coupled plasma-mass spectrometry. Ecotoxicol. Environ. Safety 38: 137-43.

de Oliveira Ribeiro CA, Belger L, Pelletier E and Rouleau C. (2002) Histopathological evidence of inorganic mercury and methyl mercury toxicity in the arctic charr (Salvelinus alpinus). Environ. Res. 90: 217-225.

Driessnack MK, Jamwal A and Niyogi S. (2017) Effects of chronic waterborne cadmium and zinc interactions on tissue-specific metal accumulation and reproduction in fathead minnow (Pimephales promelas). Ecotoxicol. Environ. Safety 140: 65-75.

Duan Z, Xing Y, Feng Z, Zhang H, Li C, Gong Z, Wang L and Sun H. (2017) Hepatotoxicity of benzotriazole 
and its effect on the cadmium induced toxicity in zebrafish Danio rerio. Environ. Pollution 224: 706-713.

Fristachi A and Choudhury H. (2017) Cadmium. In: International Encyclopedia of Public Health (Second Edition). Ed. Quah SR, Academic Press, Oxford, 316319.

Ileperuma OA. (2000) Environmental pollution in Sri Lanka: A review. J. Natn. Sci. Foundation Sri Lanka 28: 301-325.

Jayasumana C, Gunatilake S and Senanayake P. (2014) Glyphosate, hard water and nephrotoxic metals: Are they the culprits behind the epidemic of chronic kidney disease of unknown etiology in Sri Lanka? Intern. J. Environ. Res. Public Hlth. 11: 2125-2147.

Klumpp A, Bauer Konrad, Franz-Gerstein C. and Max de M. (2002). Variation of nutrient and metal concentrations in aquatic macrophytes along the Rio Cachoeira in Bahia (Brazil). Environment Intern. 28: 165-171.

Larsson A, Bengtsson B and Haux C. (1981) Disturbed ion balance in flounder, Platichthys flexus, exposed to sublethal levels of cadmium. Aquat. Toxicol. 1: 1935.

Lee JW, Choi H, Hwang UK, Kang JC, Kang YJ, Kim KI and Kim JH. (2019) Toxic effects of lead exposure on bioaccumulation, oxidative stress, neurotoxicity, and immune responses in fish: A review. Environ. Toxicol. Pharmacol. 68: 101-108.

LoDico GM, Fabio G,Giacomo D,Carlo D'ascenzi, Andrea M, Antonio V, Giuseppe G,Gaetano CandVincenzo F.(2018) Toxic metal levels in cocoa powder and chocolate by ICP-MS method after microwaveassisted digestion. Food Chem. 245: 1163-1168.

Mateus AP, Deborah MP and Adelino VMC.(2018) Stress and disease in fish. In: Fish Diseases, pp. 187-220, Academic Press.

Paulo DV, Fontes FM and Flores-Lopes F.(2012) Histopathological alterations observed in the liver of Poecilia vivipara (Cyprinodontiformes: Poeciliidae) as a tool for the environmental quality assessment of the Cachoeira River, BA. Brazilian J. Biol. 72: 131140 .

Pereira AS, Priscila AC, Alex-Alan Furtado de A, Prasad MNV, França MGC, Maura da Cunha, Raildo MJ and Pedro AOM. (2017) Morphology, ultrastructure, and element uptake in Calophyllum brasiliense Cambess. (Calophyllaceae J. Agardh) seedlings under cadmium exposure. Environ. Sci. Pollution Res. 24: 1557615588.

Perera PACT, Thenmoli V. Sundarabarathy, Thavananthan S, Suranga PK and Edirisinghe U.
(2016) Arsenic and cadmium contamination in water, sediments and fish is a consequence of paddy cultivation: Evidence of river pollution in Sri Lanka. Achievements Life Sci. 10: 144-160.

Rai R, Mishra D, Srivastav SK and Srivastav Ajai K. (2009) Ultimobranchial gland of a freshwater teleost, Heteropneustes fossilis in response to cadmium treatment. Environ. Toxicol. 24: 589-593.

Ribeiro CA, Vollaire Y, Sanchez-Chardi A and Roche H. (2005) Bioaccumulation and the effects of organochlorine pesticides, PAH and heavy metals in the eel (Anguilla anguilla) at the Camargue Nature Reserve, France. Aquat. Toxicol. 74: 53-69.

Rombough PJ and Garside ET. (1984) Disturbed ion balance in alevins of Atlantic salmon Salmo salar chronically exposed to sublethal concentrations of cadmium. Canadian J. Zool. 62: 1443-1450.

Samanta P, Im H, Na J and Jung J. (2018) Ecological risk assessment of a contaminated stream using multilevel integrated biomarker response in Carassius auratus. Environ. Pollut. 233: 429-438.

Sanches Filho P J, Jôsie Schwartz Caldas, Nathaly Nunes da Rosaand Pereira FOP. (2017) Toxicity test and Cd, $\mathrm{Cr}, \mathrm{Pb}$ and $\mathrm{Zn}$ bioccumulation in Phalloceros caudimaculatus. Egyptian J. Basic Applied Sci. 4: 206-211.

Satake F, Pádua SB and Ishikawa MM. (2009) Manejo e Sanidade de peixes em cultivo. Embrapa Amapá. pp. 330-345. ISBN 978-85-61366-01-8.

Schmalz JWF, Hernandez AD and Weis P. (2002) Hepatic histopathology in two populations of the mummichog, Fundulus heteroclitus. Marine Environ. Res. 54: 539-542.

Singh A, Sharma RK, Agrawal M and Marshall Fiona M. (2010) Health risk assessment of heavy metals via dietary intake of foodstuffs from the wastewater irrigated site of a dry tropical area of India. Food Chem. Toxicol. 48: 611-619.

Sobha K, Poornima A, Harini P and Veeraiah K. (2007) A study on biochemical changes in the fresh water fish, Catla catla (Hamilton) exposed to the heavy metal toxicant cadmium chloride. Kathmandu University J. Sci. Engineering Technol. 3: 1-11.

Svobodova Z, Machova J, Kroupove HK and Velisek J. (2017) Water Quality-Disease Relationship on Commercial Fish Farms In: Fish Diseases. Ed. Jeney Galina. Chapter 7, Academic Press, pp. 167-185.

USEPA (2002) Methods for Measuring the Acute Toxicity of Effluents and Receiving Waters to Freshwater and Marine Organisms. United States Environmental Protection Agency, 821-R-02-012. 
USEPA. (2016) Aquatic life ambient water quality criteria cadmium. https://www.epa.gov/wqc/ aquatic-life-criteria-cadmium.

van Dyk JC, Pieterse GM and van Vuren JHJ. (2007) Histological changes in the liver of Oreochromis mossambicus (Cichlidae) after exposure to cadmium and zinc. Ecotoxicol. Environ. Safety 66: 432-440.

Vazzana M, Celi M, Tramati C, Ferrantelli V, Arizza V and Parrinello N. (2014) In vitro effect of cadmium and copper on separated blood leukocytes of Dicentrarchus labrax. Ecotoxicol. Environ. Safety 102: 113-120.

Zang Y and Bolger PM. (2014) Toxic Metals: Cadmium. In: Encyclopedia of Food Safety. Ed. Motarjemi Y., Academic Press, Waltham, pp. 346-348.

WHO - World Health Organization. (1992) Cadmium. (Environmental Health Criteria, 134). Geneva. (ISBN 924 1571349.) 